\title{
Inactivation of Cdc7 kinase in mouse ES cells results in S-phase arrest and p53-dependent cell death
}

\author{
Jung Min Kim ${ }^{1}$ Kazuki Nakao², \\ Kenji Nakamura', Izumu Saito ${ }^{3}$ \\ Motoya Katsuki ${ }^{2}$, Ken-ichi Arai ${ }^{1,4}$ and \\ Hisao Masai ${ }^{1,5,6}$
}

Departments of ${ }^{1}$ Molecular and Developmental Biology and ${ }^{2}$ DNA
Biology and Embryo Engineering, ${ }^{3}$ Laboratory of Molecular Genetics,
The Institute of Medical Science, The University of Tokyo, Minato-ku,
Tokyo 108-8639, ${ }^{4}$ CREST, Tokyo 108-8639 and ${ }^{5}$ Department of Cell
Biology, Tokyo Metropolitan Institute of Medical Science, Bunkyo-ku,
Tokyo 113-8613, Japan
${ }^{6}$ Corresponding author
e-mail: hmasai@ rinshoken.or.jp

Cdc7-related kinases play essential roles in the initiation of yeast DNA replication. We show that mice lacking murine homologs of $\mathrm{Cdc} 7$ ( $\mathrm{muCdc} 7$ ) genes die between E3.5 and E6.5. We have established a mutant embryonic stem (ES) cell line lacking the muCdc7 genes in the presence of a $\operatorname{lox} P$-flanked transgene expressing $m u C d c 7$ cDNA. Upon removal of the transgene by Cre recombinase, mutant ES cells cease DNA synthesis, arresting growth with S-phase DNA content, and generate nuclear Rad51 foci, followed by cell death with concomitant increase in $\mathrm{p53}$ protein levels. Inhibition of $\mathbf{p 5 3}$ leads to partial rescue of $\mathrm{muCdc7^{-/ }}$ ES cells from cell death. muCdc7 $7^{-/} p 53^{-/}$embryos survive up to E8.5, and their blastocysts generate inner cell mass of a significant size in vitro, whereas

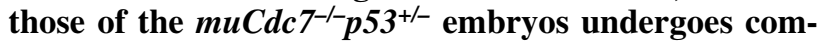
plete degeneration. These results demonstrate that, in contrast to cell cycle arrest at the $G_{1} / S$ boundary observed in yeasts, loss of $\mathrm{Cdc7}$ in $\mathrm{ES}$ cells results in rapid cessation of DNA synthesis within $S$ phase, triggering checkpoint responses leading to recombinational repair and p53-dependent cell death.

Keywords: Cdc7 kinase/conditional knockout/mouse ES cells/p53-dependent cell death/replication fork arrest

\section{Introduction}

$\mathrm{G}_{1}$-to-S transition of mammalian cells is regulated by a series of phosphorylation reactions. Among them, phosphorylation by Cdk4-CyclinD1 plays a crucial role in the decision at the restriction point to commit to the cell cycle (Baldin et al., 1993; Sherr, 1993). Downstream of Cdk4-CyclinD1, Cdk2-CyclinE plays an essential role in the progression from late $\mathrm{G}_{1}$ to $\mathrm{S}$ phase (Sherr, 1994; Ohtsubo et al., 1995). Genetic studies in yeast implicated another serine/threonine kinase in this process (Sclafani and Jackson, 1994; Stillman, 1996; Dutta and Bell, 1997; Johnston et al., 1999; Masai and Arai, 2002). Cdc7, which is activated at the $\mathrm{G}_{1} / \mathrm{S}$ boundary in a complex with Dbf4 (Chapman and Johnston, 1989; Jackson et al., 1993), is essential for initiation of $\mathrm{S}$ phase in budding yeast (Hartwell, 1971; Hollingsworth and Sclafani, 1990). Budding yeast $c d c 7^{\text {ts }}$ cells arrest with dumb-bell forms with 1C DNA content at the non-permissive temperature (Hollingsworth and Sclafani, 1990; Buck et al., 1991), indicative of cell cycle arrest at the onset of DNA synthesis. Similar 1C DNA arrest was also observed in $h s k l^{\text {ts }}$, the fission yeast homolog of CDC7 (Masai et al., 1995; Brown and Kelly, 1998; Takeda et al., 1999). Studies in budding yeast indicated that the Cdc7 functions are required throughout $S$ phase to permit firing of each replication origin on the chromosomes (Bousset and Diffley, 1998; Donaldson et al., 1998; Zou and Stillman, 2000). These results indicate that $\mathrm{Cdc} 7$ kinase is required not only for initiation of S phase, but also for initiation of DNA replication at each replication origin.

Genetic and biochemical studies indicate that the minichromosome maintenance (MCM) complex is the primary target of Cdc7 kinases. MCM may function as a cellular replicative DNA helicase (Chong et al., 1996; Kearsey et al., 1996; Aparicio et al., 1997; Ishimi, 1997), and it has been proposed that $\mathrm{Cdc} 7$ may activate MCM helicase at the origins (Sclafani, 2000; Labib and Diffley, 2001; Lei and Tye, 2001). Cdc7 phosphorylates the MCM2 component of the MCM complex both in vivo and in vitro (Lei et al., 1997; Sato et al., 1997; Brown and Kelly, 1998; Weinreich and Stillman, 1999), although precise mechanisms of origin activation by Cdc7-mediated phosphorylation of MCM remain elusive.

The structural and functional homologs of Cdc7 kinase have been identified in higher eukaryotes, including Xenopus, mouse and human (Jiang and Hunter, 1997; Sato et al., 1997; Kim et al., 1998). Microinjection of an antibody against ASK, the regulatory subunit for huCdc7, or of that against huCdc7, blocked S-phase initiation in mammalian cells (Jiang et al., 1999; Kumagai et al., 1999), and immunodepletion of Cdc7 from Xenopus egg extracts inhibited DNA replication (Roberts et al., 1999; Jares and Blow, 2000; Walter, 2000), indicating the requirement of $\mathrm{Cdc} 7$ kinase for metazoan DNA replication. However, the precise understanding of functions of mammalian $\mathrm{Cdc} 7$ kinase in cell proliferation requires genetic characterization.

In this study, we attempt to genetically dissect the roles of mammalian Cdc7 kinase in control of cell proliferation and differentiation. We first generated murine $C d c 7$ $(m u C d c 7)$ knockout mice and showed that they are early embryonic lethal. We then generated conditional $m u C d c 7$ deficient embryonic stem (ES) cell lines and showed that muCdc7 is essential for DNA replication of ES cells. Furthermore, our results revealed unexpected phenotypes of $C d c 7$ knockout ES cells, namely S-phase arrest and p53-dependent cell death, indicating that $S$ phase is being monitored very strictly by the p53-dependent checkpoint 


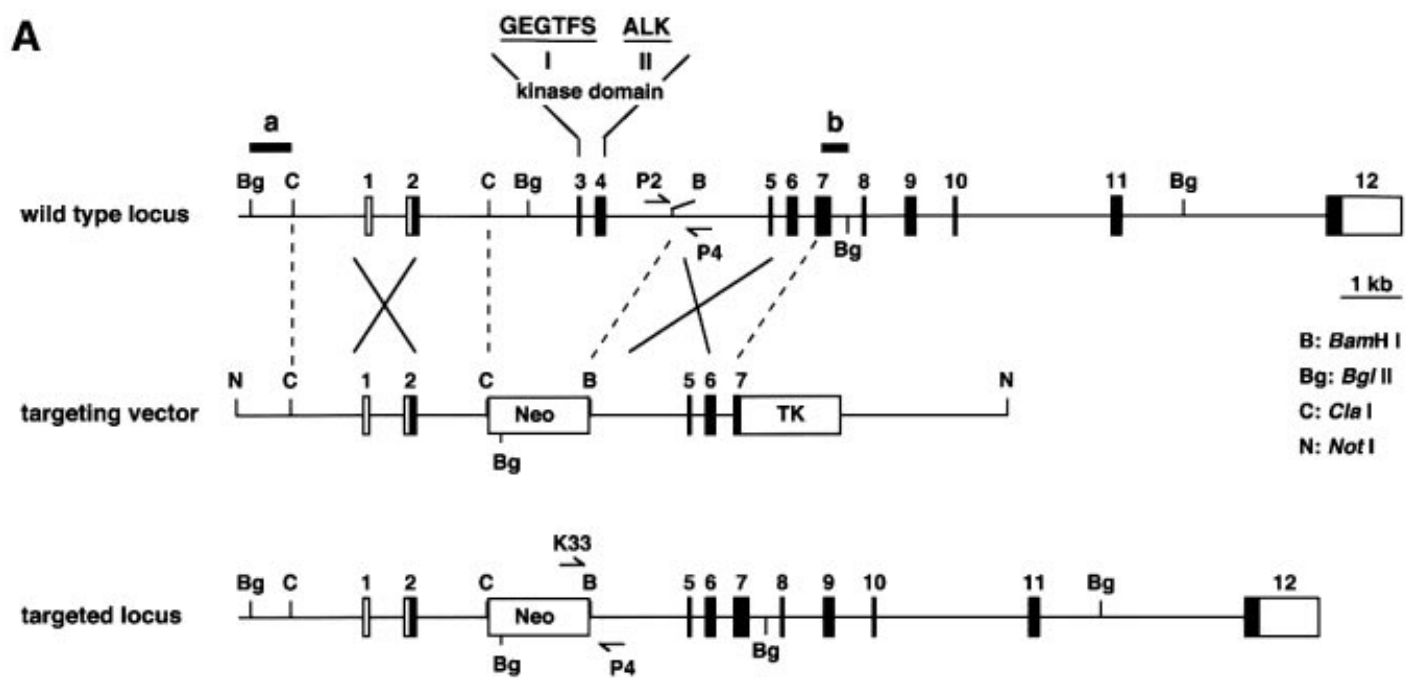

B

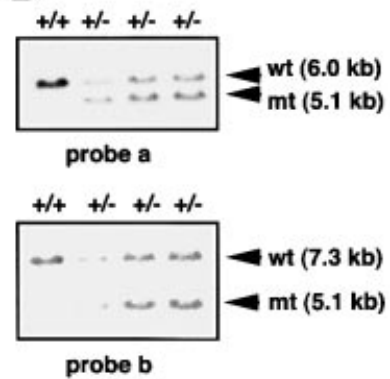

C

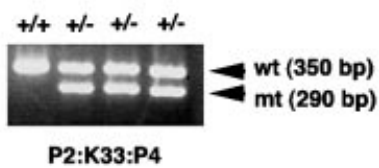

D

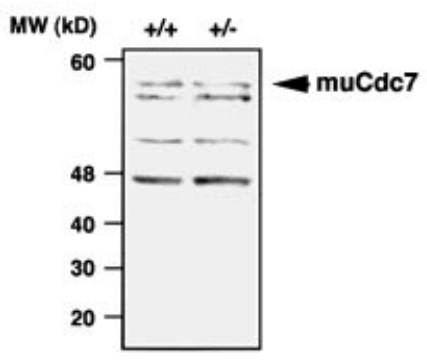

Fig. 1. Targeted disruption of the $m u C d c 7$ gene. (A) Restriction maps of the wild-type $m u C d c 7$ gene, the targeting vector and the mutant locus resulting from homologous recombination. The numbered boxes indicate exons. Genomic fragments used as probes for Southern blotting are indicated by horizontal bars labelled a and b. The positions of the primers used for genotyping mice and embryos are shown by converging arrows P2/P4 and K33/ P4. (B) Identification of $m u C d c 7^{+/-}$ES clones by Southern blot analysis. Genomic DNA was digested with BglII and hybridized with either a $5^{\prime}$ (a) or $3^{\prime}$ (b) probe. The hybridizing DNA fragments of wild-type (wt) and mutant (mt) alleles are shown by arrows. (C) PCR genotyping of mice and embryos from a $m u C d c 7$ heterozygous breeding. Three primers (P2/K33/P4) were included in PCRs to amplify a 350 or 290 bp fragment specific for the wild type or a mutant allele, respectively. (D) Western blotting of whole-cell extracts from $m u C d c 7^{+/+}$and $m u C d c 7^{+/-}$ES cells using anti-muCdc7 antibody as described previously (Kim et al., 1998). The arrow indicates the endogenous 532 amino acid muCdc7 polypeptide expressed in ES cells. There are extra bands that react non-specifically with the antibody.

pathway to ensure high-fidelity genome inheritance in ES cells.

\section{Results}

\section{Disruption of the muCdc7 gene}

We previously reported that the $m u C d c 7$ gene, located on the mouse chromosome 5E5, consists of 12 exons (Kim et al., 1998). In order to genetically dissect the functions of mammalian $\mathrm{Cdc} 7$ kinase, we attempted to disrupt the $m u C d c 7$ gene through homologous recombination. Our strategy was to replace exons 3 and 4, encoding kinase domains I and II, with a neo ${ }^{\mathrm{r}}$ resistance cassette (Figure 1A). This manipulation was expected to completely inactivate the kinase activity of muCdc7. Cells from two independent ES lines containing a disrupted $m u C d c 7$ allele were injected into C57BL/6 blastocysts, and the resulting chimeras were backcrossed to C57BL/6 wild-type animals to generate heterozygous animals. The successful disruption of the $m u C d c 7$ locus was confirmed by Southern blotting and PCR (Figure 1B and C). Western blotting of the extracts prepared from $m u C d c 7^{+/+}$and $m u C d c 7^{+/-}$ES cells indicated the absence of aberrant
Table I. Genotypes of offspring from $m u C d c 7$ heterozygous intercrosses

\begin{tabular}{lrrcc}
\hline Age & $+/+$ & \multicolumn{1}{c}{+-} & $-l-$ & Total No. \\
\hline E3.5 & 6 & 54 & 15 & 75 \\
E6.5 & 8 & 27 & $(1)^{\mathrm{a}}$ & 36 \\
E7.5 & 12 & 40 & 0 & 52 \\
E8.5 & 26 & 60 & 0 & 86 \\
Weaning & 512 & 1080 & 0 & 1592 \\
\hline
\end{tabular}

${ }^{a}$ Number in parentheses indicates the embryo that was about to be resorbed.

forms of muCdc7 generated from the knockout locus (Figure 1D). No homozygous null animals were observed in a total of $>1500$ live births from $C d c 7^{+/-}$heterozygous intercrosses using either of the two founder lines (Table I). Wild-type and heterozygous mice were born at the expected frequencies, and the heterozygous mice appeared normal, healthy and fertile.

To determine at what embryonic stage $m u C d c 7^{-1-}$ null embryos die, we analyzed embryos from heterozygous intercrosses at different stages of gestation. Null blastocysts (E3.5) were identified, and their morphology was 
A

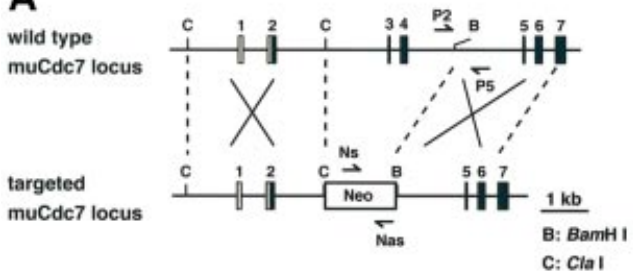

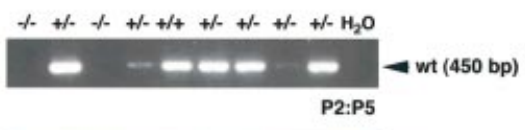

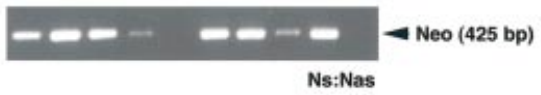

B
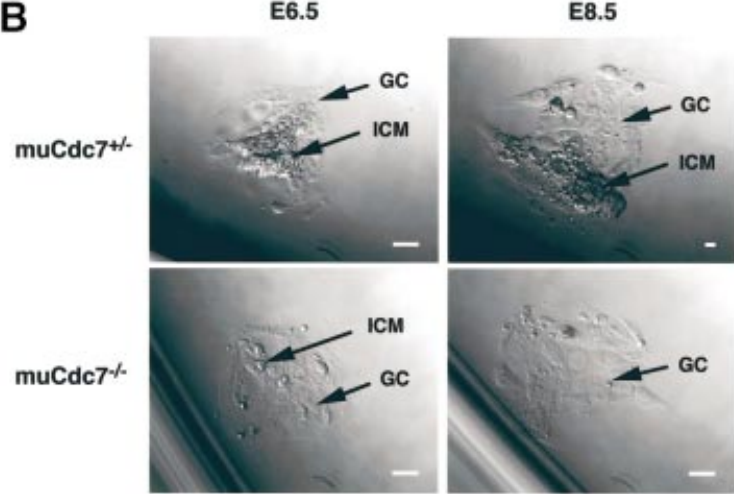

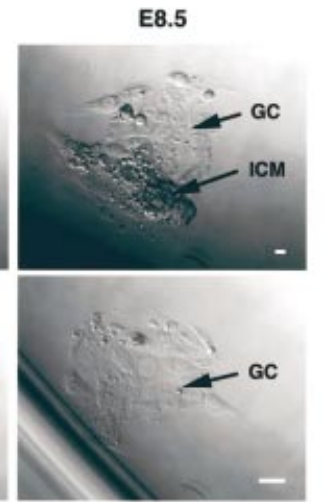

C

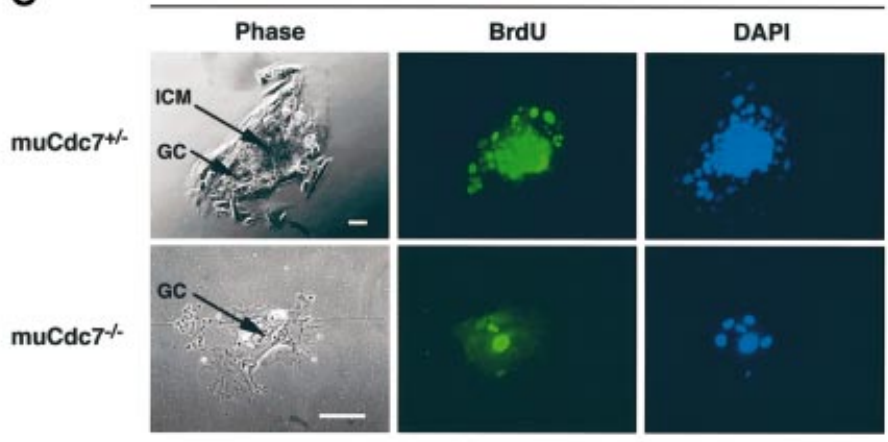

muCdc7 $7^{+-}$
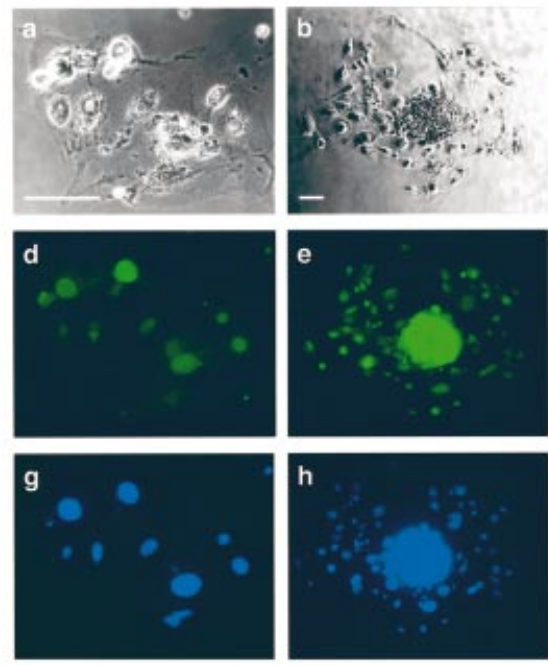

D muCdc $^{-1}$
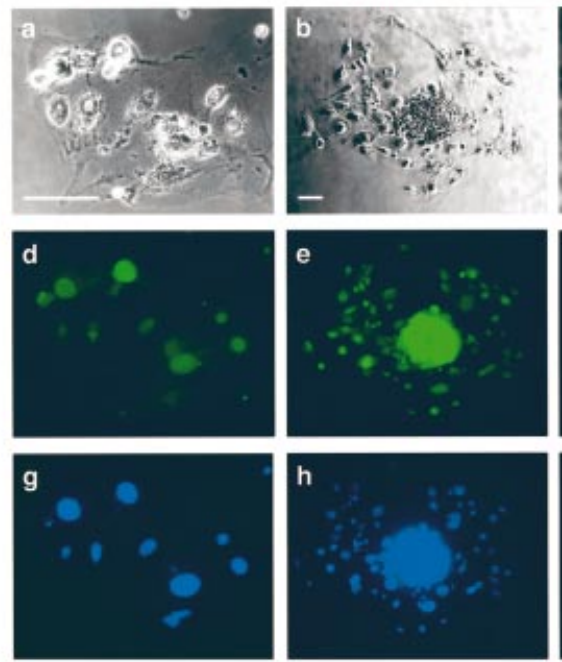
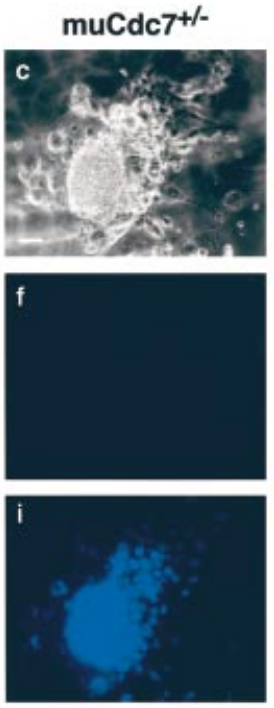

Fig. 2. Growth and DNA synthesis of $m u C d c 7$-deficient embryos in culture. (A) The converging arrows, P2/P5 and Ns/Nas, indicate the primers used for genotyping blastocyst outgrowths, which detect the wild-type (wt) and mutant (Neo) alleles, respectively. (B) Blastocysts from $m u C d c 7$ heterozygous intercrosses were cultured in vitro for 5 days and photographed using phase-contrast microscopy. Arrows point to the ICM and the trophoblast GC. Scale bar $=50 \mu \mathrm{m}$. (C) Blastocysts from $m u C d c 7$ heterozygous intercrosses were cultured in vitro until E8.5, and were incubated in the presence of $10 \mu \mathrm{M}$ BrdU for $3 \mathrm{~h}$. Blastocyst outgrowths were processed for indirect immunofluorescence using anti-BrdU antibody (green) and counterstained with 4',6-diamidino-2-phenylindole (DAPI; blue). Scale bars $=100 \mu \mathrm{m}$. (D) Immunohistochemical analysis of $m u C d c 7^{-1-}$ GCs. Blastocysts grown in culture as in (C) were fixed and stained with anti-muCdc7 antibody (d and e, green) or control IgG (f). Nuclei were detected by DAPI staining (g, h and $\mathrm{i}$; blue). a, b and c, phase-contrast images of the cells. The genotype of each embryo was determined by PCR. Scale bars $=100 \mu \mathrm{m}$.

indistinguishable from that of the wild-type or heterozygous blastocysts (data not shown). However, among 174 embryos between E6.5 and E8.5, only one $m u C d c 7$ null embryo (E6.5) was detected that was about to be resorbed (Table I). These results indicate that $m u C d c 7$ null embryos are viable and normal until E3.5, but die between E3.5 and E6.5. The apparent death of the null embryos after E3.5 may be due to run-out of the maternal stock and/or to active cell death caused by unknown mechanisms.

\section{The muCdc7 mutation causes degeneration of in vitro cultured blastocyst outgrowths}

To examine growth of blastocysts in vitro, blastocysts from $\mathrm{muCdc} 7^{+/-}$heterozygous intercrosses were collected, cultured in vitro, and subsequently genotyped by PCR (Figure 2A). After 24-48 h in culture, the spherical blastocysts flattened onto the culture dish and the inner cell mass (ICM) grew a mound on top of the trophoblast giant cells (GCs) (Figure 2B). When $m u C d c 7$ null and heterozygous embryos were cultured in vitro, they grew at similar rates through E5.5. However, the sizes of the
ICM of $m u C d c 7$ null blastocysts were smaller than those of the wild-type counterpart at E6.0 (data not shown). Subsequently, $m u C d c 7^{-/}$ICM diminished further in size and completely disappeared by E8.5, leaving behind a monolayer of GCs with large nuclei (Figure 2B). Analysis of $C d c 7$ null GCs by phase-contrast microscopy and BrdU labeling demonstrated that they were alive and undergoing DNA replication at E8.5 (Figure 2C). GCs are mitotically inactive and undergo repeated DNA replication, generating a polyploid nucleus and a large cytoplasm (Rugh, 1990). Immunostaining of in vitro cultured blastocysts with a muCdc7-specific antibody indicates the presence of muCdc7 protein in $m u C d c 7^{--}$GCs (Figure 2D). Thus, the survival of $m u C d c 7^{-1-} \mathrm{GCs}$ is likely to be due to the presence of residual $\mathrm{Cdc} 7$ protein that persists in the undividing cells.

\section{Generation of conditional muCdc7-deficient ES cell lines}

The above results indicate that the muCdc7 functions are essential for early embryogenesis or cell proliferation 
A

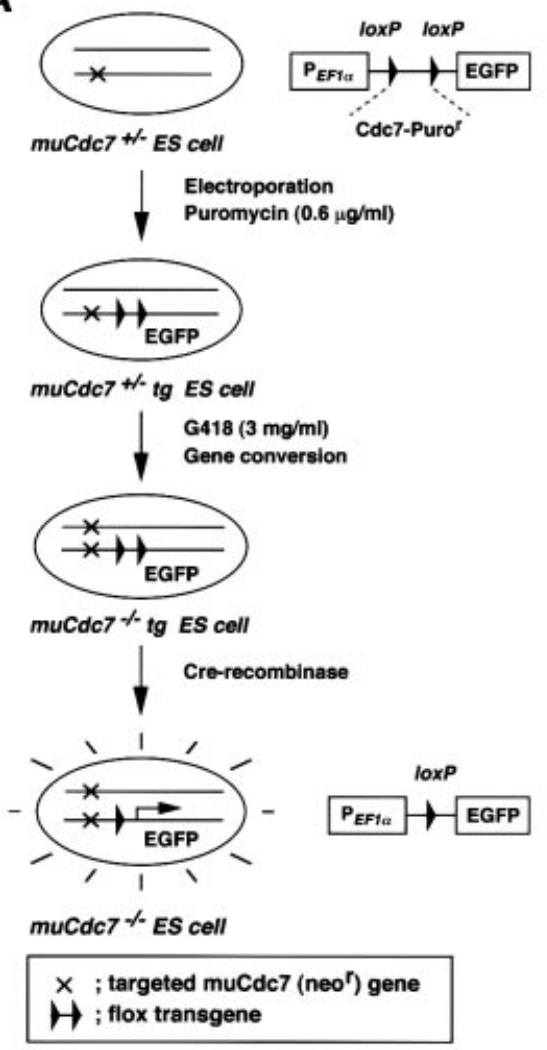

B

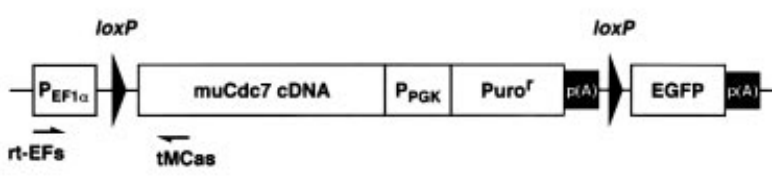

C

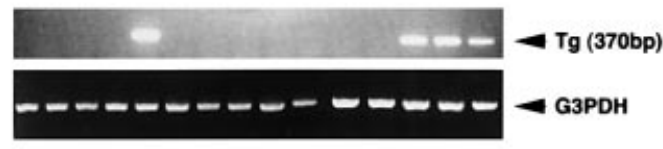

D

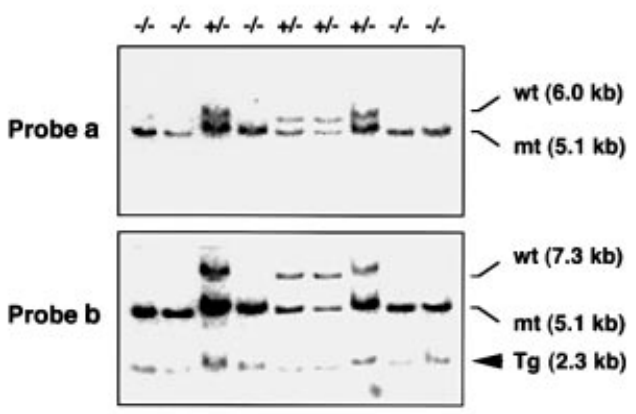

E

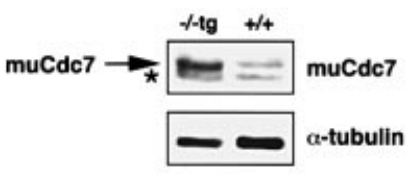

Fig. 3. Generation of conditional $m u C d c 7$-deficient ES cell lines. (A) Strategy for the generation of conditional $m u C d c 7^{-/-}$ES cell lines carrying a Cre-removable (flox) muCdc7 transgene. (B) A schematic drawing of the structure of muCdc7 flox transgene. $\mathrm{p}(\mathrm{A})$ indicates a polyadenylation signal. (C) RT-PCR analysis of total RNA isolated from $m u C d c 7^{+/}$tg ES clones. The primer pair, rtEFs/tMCas, shown in (B), was used to detect the expression of a transgene (upper panel). Expression of G3PDH was also examined as a control (lower panel). (D) Southern blotting analysis of conditional $m и C d c 7$-deficient ES clones. BglII-digested genomic DNA was hybridized with the probe a or b (see Figure 1A). Tg indicates the bands derived from the transgene. (E) Expression of the transgene-encoded muCdc7 protein in conditional $m u C d c 7$-deficient ES clones. Whole-cell extracts prepared from the indicated cells were analyzed by immunoblotting with anti-muCdc7 (upper) or anti- $\alpha$-tubulin (lower) antibody. A non-specifically reacting band is indicated by the asterisk.

per se, or for both. In order to determine whether muCdc7 functions are required for cell proliferation per se, we decided to generate mutant ES cell lines in which inactivation of muCdc7 can be conditionally induced (Figure 3A). For this purpose, we constructed a flox muCdc7 transgene, which is flanked by the loxP sites and can be excised later with Cre recombinase. The cDNA used for the transgene was derived from one of the $m u C d c 7$ alternatively spliced forms (Kim et al., 1998) and encodes a 532 amino acid polypeptide which is fully active for phosphorylation of the MCM complex in vitro (J.M.Kim and H.Masai, unpublished data). The transgene plasmid also contains a promoterless EGFP gene downstream of the transgene, which is expressed only after excision of the loxP-flanked transgene and therefore can serve as an indicator for the efficiency of Cre-mediated excision (Figure 3B). The transgene was transfected into $\mathrm{muCdc} 7^{+/-}$heterozygous ES cells by electroporation, and puromycin-resistant $m u C d c 7^{+/}$tg ES clones carrying the transgene were identified by RT-PCR (Figure 3C). Fifteen out of 48 puromycin-resistant clones were shown to express transgene-derived mRNA. Four out of 15 clones carried a single copy of the transgene. We then converted the endogenous wild-type allele to the disrupted one containing the neomycin marker through gene conversion. This was accomplished simply by elevating the concentration of G418 to $3 \mathrm{mg} / \mathrm{ml}$ (Mortensen et al., 1992). It caused the selection of ES cells homozygous for the targeted allele, which are expected to display resistance to a higher concentration of G418 due to the presence of two copies of the $n e o^{\mathrm{r}}$ gene. Using one of the $m u C d c 7^{+/} \operatorname{tg} \mathrm{ES}$ cells carrying a single copy transgene, 38 surviving clones were isolated. Southern blot analysis indicated that 11 had undergone expected gene conversion, generating conditional $m и C d c 7$-deficient $\left(m u C d c 7^{-/} \operatorname{tg}\right)$ ES cell lines (Figure 3D). Western blotting showed that the expression level of the transgene-encoded muCdc7 is $\sim 3-5$ times higher than that of endogenous protein (Figure 3E). The homozygous $m u C d c 7$ null ES cell lines could not be established in the absence of the transgene (data not shown), suggesting that muCdc7 functions are essential for cell proliferation of ES cells.

\section{muCdc7 is essential for ES cell viability}

We subsequently infected these $m u C d c 7^{-/} \operatorname{tg}$ ES cells with adenoviruses expressing Cre recombinase (Ad-Cre) to excise the transgene. FACS analysis indicated that nearly $100 \%$ of the cells were positive for EGFP as early as day 1 
after infection and its extent reached a maximum at day 3 (Figure 4A). This was also confirmed by examining the cells under a microscope (Figure 4B). At day 4 after infection, Ad-Cre-infected $m u C d c 7^{-/}$tg ES cells had started to detach from the plates (see below), and EGFP expression also decreased. We showed that muCdc7 protein expressed from the transgene disappeared at day 2 after infection (Figure 4C). Thus, we were able to establish mutant ES cell lines in which inactivation of the $m u C d c 7$ gene could be conditionally induced.

We next examined the growth properties of the $m u C d c 7^{-/} \operatorname{tg}$ ES cells after infection with Ad-Cre. The increase in cell numbers stopped almost immediately (Figure 5A). As the control, $m u C d c 7^{+/}$tg ES cells carrying the same transgene kept increasing in number under the same condition, although the rate decreased compared with non-infected cells, presumably due to the effect of adenovirus infection. $\left[{ }^{3} \mathrm{H}\right]$ thymidine incorporation was measured in these cell lines to determine the level of DNA synthesis. In $\mathrm{muCdc} 7^{-/} \mathrm{tg}$ ES cells, DNA synthesis was almost completely inactivated as early as day 1 after infection with Ad-Cre (Figure 5B). BrdU incorporation was also significantly reduced at day 2 after infection and was completely lost at day 3 (Figure 5C). These results indicate that loss of muCdc7 results in rapid cessation of DNA synthesis.

\section{Depletion of muCdc7 in ES cells results in accumulation of S-phase cells and formation of nuclear Rad51 foci}

We examined cell cycle distribution of Ad-Cre-infected $m u C d c 7^{-/} \mathrm{tg}$ ES cells. Wild-type ES cells proliferating in an undifferentiated state are characterized by unique cell cycle distribution, with $\sim 20 \%$ of the cells being in $\mathrm{G}_{1}$ phase and $\sim 80 \%$ in $\mathrm{S}$ and $\mathrm{G}_{2} / \mathrm{M}$ phases (Savatier et al., 1994). Prior to infection, $m u C d c 7^{-/} \operatorname{tg}$ ES cells essentially exhibited the same pattern as the wild-type ES cells (Figure 5D; data not shown). After infection of Ad-Cre, $\mathrm{G}_{1}$ phase peak decreased and the population of $S / G_{2}$ phase cells increased in $\mathrm{muCdc}^{-/-} \mathrm{tg}$ ES cells (Figure 5D). This is expected from the results in the previous section, since rather quick arrest of DNA synthesis after excision of the transgene would lead to accumulation of S-phase cells.

The above results indicate that muCdc7 inactivation in ES cells induces the arrest of replication forks, generating signals for DNA damage or DNA structure checkpoint. Upon DNA damage, recombination-dependent repair processes are induced, and this leads to the appearance of Rad51 foci in the nuclei (Haaf et al., 1995). We investigated whether Rad51 protein generates foci in cells depleted for muCdc7. Ad-Cre-infected $m u C d c 7^{-1} \operatorname{tg}$ ES cells exhibited typical Rad51 nuclear foci, whereas wildtype ES cells showed no nuclear foci under the same condition (Figure 6A). This is consistent with the idea that the arrested replication forks are being repaired in a recombination-dependent manner. Similar focus formation was also observed in hydroxyurea (HU)-treated or $\gamma$-ray-irradiated wild-type ES cells (Figure 6A).

\section{Activation of $G_{2} / M$ checkpoint in muCdc7 $^{-/-}$ ES cells}

The block of replication forks by DNA damage or HU is known to induce $\mathrm{G}_{2} / \mathrm{M}$ blocks through inactivation of
A

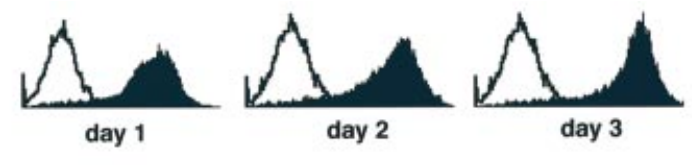

B
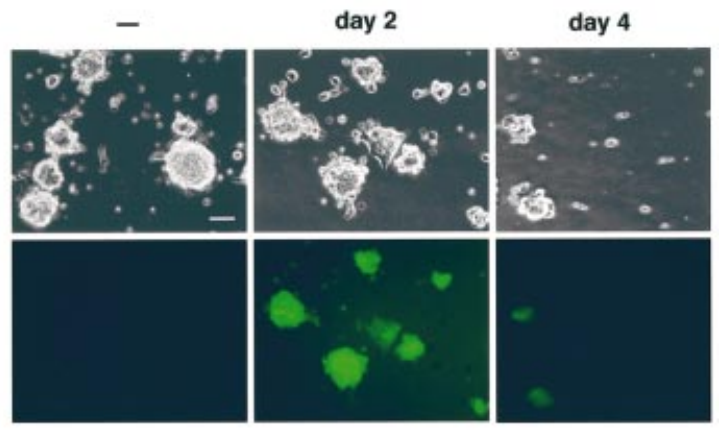

C

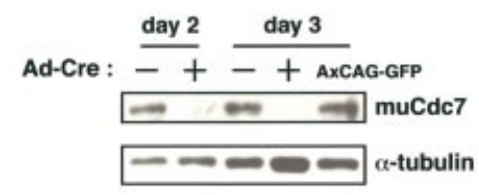

Fig. 4. Excision of the transgene in $m u C d c 7^{-1-} \operatorname{tg}$ ES cells by infection of Ad-Cre. (A) Flow cytometry analysis of green fluorescent protein (GFP) expression in $m u C d c 7^{-1} \operatorname{tg}$ ES cells at indicated times after infection of Ad-Cre. The open and filled histograms indicate the fluorescence profile of uninfected and infected $m u C d c 7^{-1} \operatorname{tg}$ ES cells, respectively. (B) Phase-contrast and fluorescence microscope evaluation of GFP expression in $m u C d c 7^{-1-} \operatorname{tg}$ ES cells infected with Ad-Cre. Left, uninfected; middle, 2 days after infection; right, 4 days after infection. Upper, phase contrast; lower, fluorescence microscope. Scale bar $=40 \mu \mathrm{m}$. (C) Expression of the transgene-encoded muCdc7 protein was detected by western blotting at days 2 and 3 after infection of $m u C d c 7^{-/}$tg ES cells with Ad-Cre. Upper, anti-muCdc7 antibody (Kim et al., 1998); lower, anti- $\alpha$-tubulin antibody. '-' and '+' indicate uninfected and infected cells, respectively. The rightmost lane represents the same cells infected with a control adenovirus, AxCAG-GFP (kindly provided by Dr Yumiko Kamogawa), for 3 days.

Cdc25 phosphatase (Furnari et al., 1997; Sanchez et al., 1997). We investigated whether muCdc7 inactivation in ES cells induces the $G_{2} / M$ checkpoint by examining the phosphorylation on tyrosine 15 of Cdc2 kinase, a target site of Cdc25 phosphatase. We observed a sharp increase in tyrosine 15 phosphorylation upon inactivation of muCdc7 (Figure 6B). We also conducted immunostaining with an antibody that detects the phosphorylated serine 10 of histone $\mathrm{H} 3$. The $\mathrm{H} 3$ phosphorylation has been reported to be an excellent marker for chromosome condensation during mitotic prophase in mammalian cells (Bradbury, 1992). Ad-Cre-infected $m u C d c 7^{-/} \operatorname{tg}$ ES cells were virtually negative with this antibody, whilst $m u C d c 7^{+/+} \mathrm{ES}$ cells treated similarly showed significant fractions of immunopositive cells (Figure 6C). These results indicate that loss of muCdc7 induces $\mathrm{G}_{2} / \mathrm{M}$ checkpoint signals.

\section{Induction of cell death and increased p53 expression in muCdc7-/- ES cells}

At day 4 after infection, the Ad-Cre-infected $m u C d c 7^{-1-} \mathrm{tg}$ ES cells started to detach from the plates and lose viability. We therefore examined whether infected $m u C d c 7^{-/} \operatorname{tg}$ ES cells were undergoing apoptosis using terminal deoxynucleotidyltransferase-mediated dUTP nick end labeling 

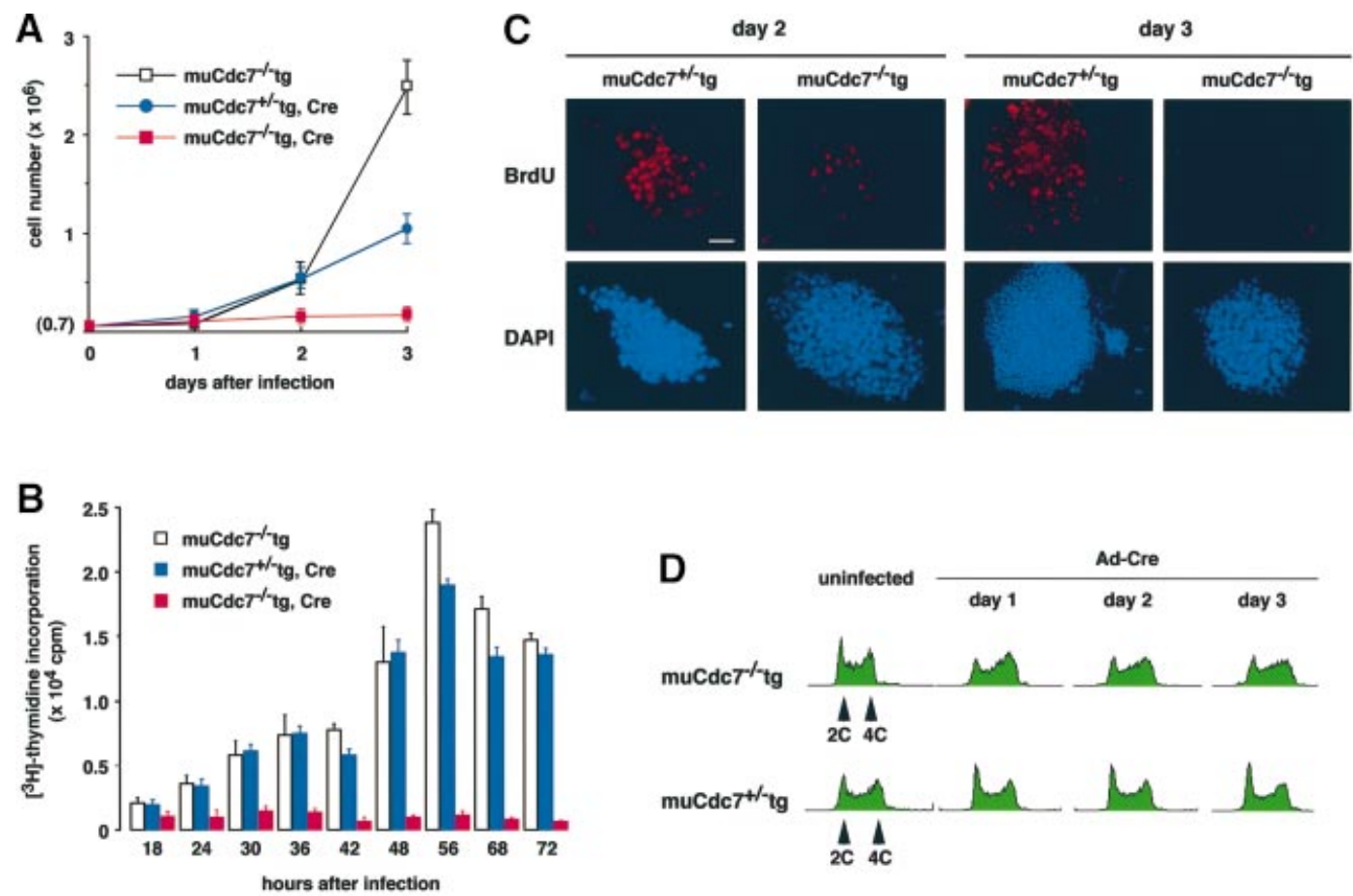

Fig. 5. Cell proliferation, DNA synthesis and cell cycle profile of $m u C d c 7^{-1} \operatorname{tg}$ ES cells after removal of the transgene. $m u C d c 7^{-1} \operatorname{tg}$ and $m u C d c 7^{+/} \operatorname{tg}$ ES cells were infected with Ad-Cre at a m.o.i. of 50. (A) The numbers of viable cells, as indicated in the figure, were counted at various time points (0-3 days) after infection. (B) The same set of cells were incubated for $1 \mathrm{~h}$ in the presence of $1 \mu \mathrm{Ci}$ of $\left[{ }^{3} \mathrm{H}\right]$ thymidine at different times after infection, and its incorporation was measured. In uninfected $m u C d c 7^{-1-}$ tg or Ad-Cre-infected $m u C d c 7^{+/-} \operatorname{tg}$ ES cells, the drops in $\left[{ }^{3} \mathrm{H}\right]$ thymidine incorporation at 68 and $72 \mathrm{~h}$ after infection are the results of overgrowth. (C) At days 2 or 3 after infection, cells were pulse-labeled with $10 \mu \mathrm{M}$ BrdU for 20 min, fixed and incubated with anti-BrdU antibody to detect BrdU incorporation (upper, red). DNA was detected by DAPI staining (lower, blue). Scale bar $=20 \mu \mathrm{m}$. (D) Flow cytometry analysis of DNA content of $m u C d c 7^{-1} \operatorname{tg}$ (upper) or $m u C d c 7^{+/} \operatorname{tg}$ (lower) at indicated times after infection of Ad-Cre. In (A) and (B), the values represent average of three independent experiments.

(TUNEL) assays. Figure 7A shows that most of the Ad-Cre-infected $m u C d c 7^{--}$tg ES cells at day 3.5 were TUNEL positive. These observations indicate that the depletion of muCdc7 protein in ES cells results in growth arrest in S phase and eventually leads to cell death. The occurrence of cell death was also indicated by the appearance of DNA fragmentation in $m u C d c 7^{--}$ES cells (Figure 7B).

The observed cell death could simply be due to permanent cell cycle arrest at $\mathrm{S}$ phase caused by lack of muCdc7 protein. Alternatively, active cell death may be responsible for this. In response to DNA damage induced by UV or $\gamma$-ray irradiation, p53 is stabilized and accumulates in the nucleus, where it induces the expression of genes involved in cell cycle arrest or apoptosis (Carr, 1996; Hansen and Oren, 1997; Levine, 1997). We have noted that levels of p53 and phosphorylation on serine 15 of p53 (Banin et al., 1998; Canman et al., 1998; Tibbetts et al., 1999; Shieh et al., 2000) increased in infected $m u C d c 7^{-/} \operatorname{tg}$ ES cells, whereas the wild-type ES cells showed no increase under the same conditions (Figure 7C).

We then conducted immunostaining to determine whether increased p53 protein localized in the nucleus. Previous studies demonstrated that embryonic carcinoma cells and undifferentiated ES cells contain cytoplasmic wild-type p53 protein under normal growing conditions (Lutzker and Levine, 1996; Sabapathy et al., 1997; Aladjem et al., 1998). In uninfected or Ad-Cre-infected wild-type ES cells, p53 protein was almost exclusively localized in the cytoplasm. In contrast, Ad-Cre-infected $m и C d c 7^{-/} \operatorname{tg}$ ES cells exhibited staining of higher intensity, which was detected in both the cytoplasm and nuclei (Figure 7D). These results indicate that muCdc7 inactivation in ES cells resulted in induction and nuclear localization of p53 protein. In order to examine p53mediated transcriptional activation in Ad-Cre-infected $m u C d c 7^{-1} \operatorname{tg}$ ES cells, we conducted northern blot analysis of endogenous p53 target genes (Figure 7E). p21, mdm2 and cyclin $G$ mRNA levels increased, while bax-la and gadd45 levels stayed relatively constant. These data indicate that p53 is transcriptionally active in $m u C d c 7$ deficient ES cells. Western blot analysis revealed that the level of $\mathrm{p} 21$ protein increased in infected $m u C d c 7^{-/} \operatorname{tg}$ ES cells (Figure 7C).

Our results suggest a possibility that aberrant replication structures resulting from S-phase arrest in $m u C d c 7^{-/-}$cells may be sensed as checkpoint-inducing signals, eventually leading to p53-dependent apoptosis.

\section{Cell death in muCdc7-/- ES cells requires p53 function}

In order to address whether cell death in $m u C d c 7^{-/-}$ES cells depends on p53 function, we have used pifithrin- $\alpha$, which is known to prevent nuclear accumulation of p53 (Komarov et al., 1999). Treatment of Ad-Cre-infected $m u C d c 7^{-1} \operatorname{tg}$ ES cells with pifithrin- $\alpha$ led to a significant increase of surviving cells (Figure 8A). Under this condition, the levels of p53 and p21 proteins decreased (Figure 8B), indicating that the drug decreased stability of the $\mathrm{p} 53$ protein. We also examined the effect of expression 
A

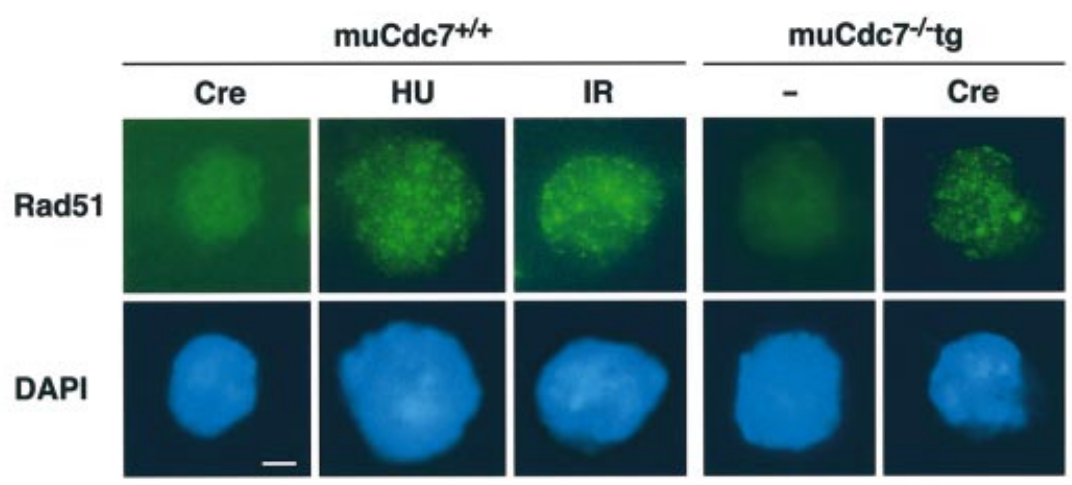

B

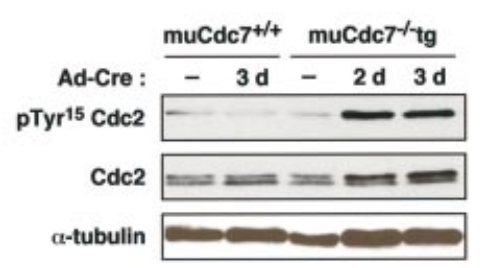

C

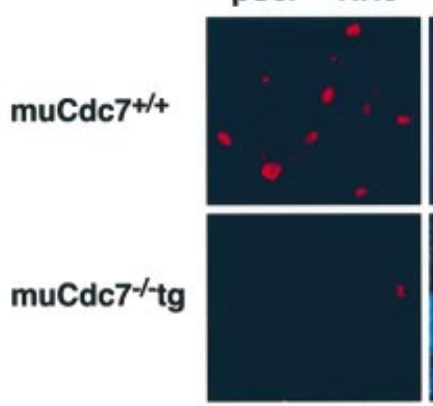

DAPI

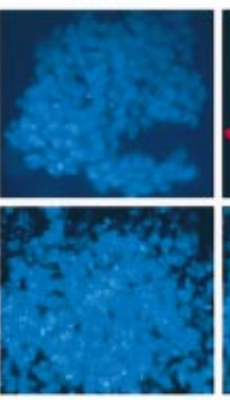

merge

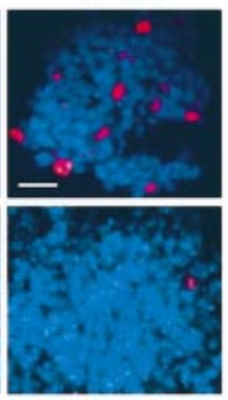

Fig. 6. Activation of $\mathrm{G}_{2} / \mathrm{M}$ checkpoint in $m u C d c 7^{-/-} \mathrm{ES}$ cells. $m u C d c 7^{+/+}$and $m u C d c 7^{-/} \mathrm{tg}$ ES cells were infected with Ad-Cre at a m.o.i. of 50 . (A) The cells were infected with Ad-Cre for 2.5 days (Cre), treated with HU for $12 \mathrm{~h} \mathrm{(2} \mathrm{mM,} \mathrm{HU),} \gamma$-irradiated (10 Gy, IR) or untreated (-). Rad51 nuclear foci were detected by immunostaining using anti-Rad51 antibody (upper, green), and the nucleus was localized by DAPI (lower, blue). Scale bar $=1 \mu \mathrm{m}$. (B) $m u C d c 7^{+/+}$and $m u C d c 7^{-/}$tg ES cells were harvested at the indicated times after infection, and the cell extracts were analyzed by immunoblotting with antibodies against Cdc2, phosphorylated $\mathrm{Tyr}^{15}$ of $\mathrm{Cdc} 2$ and $\alpha$-tubulin. (C) Cells infected for 2.5 days were stained with an antibody specific to $\mathrm{Ser}^{10}$ phosphohistone $\mathrm{H} 3$ (pSer ${ }^{10} \mathrm{HH}$, red) to detect those in mitosis. Cells were counterstained with DAPI to localize the nucleus (blue). Merge: merged images of $\mathrm{pSer}^{10} \mathrm{HH} 3$ and DAPI staining. Scale bar $=10 \mu \mathrm{m}$.

of human papilloma virus E6 protein, which inactivates p53 (Thompson et al., 1997), and the Mdm2 protein, which promotes degradation of p53 (Haupt et al., 1997; Kubbutat et al., 1997). Both E6 and Mdm2 proteins partially prevented the cell death of $m u C d c 7^{--}$ES cells (Figure $8 \mathrm{C}$ ), whereas they did not affect the viable cell numbers in $m u C d c 7^{+/+}$cells under the same condition (data not shown). These results indicate that cell death observed in $m u C d c 7^{-/}$ES cells requires p53 function.

\section{Partial rescue of muCdc7-/- embryonic lethality by p53 null mutation}

To examine whether the early embryonic lethality of the ти $C d c 7$-deficient embryos would be rescued by the loss of p53 function, 190 pups from double heterozygous crosses $\left(\mathrm{muCdc} 7^{+/}-\mathrm{p} 53^{+/-} \times \mathrm{muCdc} 7^{+/} \mathrm{p} 53^{+/-}\right)$were genotyped by PCR. None of them was homozygous for muCdc7 (data not shown), indicating that the lethal phenotype could not be rescued in a $p 53$ null background. Next, 94 embryos at E7.5, 96 embryos at E8.5 and 65 embryos at E9.5 from double heterozygous crosses were isolated and genotyped by PCR (Figure 9A). Interestingly, four E7.5 and two E8.5 embryos were homozygous for both $m u C d c 7$ and p53 (Figure 9A; Table II), although they were growth retarded in development. No double knockout embryos survived past E9.5. These results indicate that loss of p53, leading, presumably, to reduced apoptosis, can partially rescue the early embryonic lethality of $m u C d c 7$-deficient embryos.

To further confirm this notion, we examined $m u C d c 7^{-/-}$ blastocysts. E3.5 blastocysts were collected from double heterozygous crosses, cultured in vitro until E8.5, and subsequently genotyped. $m u C d c 7^{-/-}$outgrowth in the $p 53$ null background developed ICM, although its size was smaller than that of the wild type, whereas $m u C d c 7^{-/-}$ outgrowths in either a wild-type or heterozygous $p 53$ background developed no ICM at E8.5 (Figure 9B), as was shown above (Figure 2B). This indicates that loss of p53 can partially rescue survival of $m u C d c 7^{-/-}$ICM in vitro.

Taken together, our observations strongly indicate that loss of Cdc7 functions results in p53-dependent cell death in ES cells and in early embryos.

\section{Discussion}

The machinery of DNA replication is strikingly conserved throughout evolution (Stillman, 1996). In eukaryotes, initiation and progression of DNA replication need to be under strict regulation during normal cell cycle progression as well as in an emergency (such as in the presence of DNA-damaging agents). To achieve this exquisite regulation, protein kinases play crucial roles. $\mathrm{Cdc} 7$, originally discovered in budding yeast, is expected to play conserved essential functions in DNA replication (Sclafani, 2000; 
A
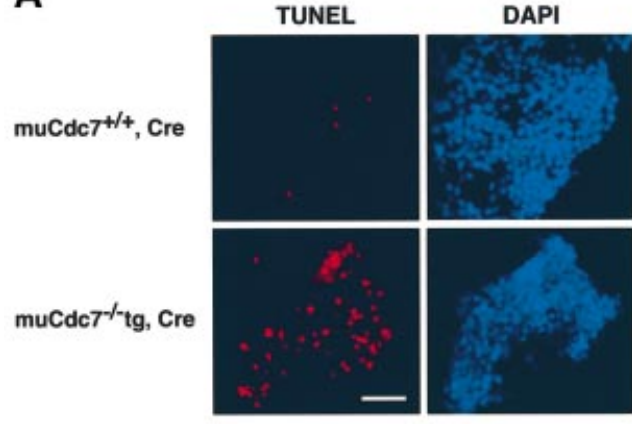

B

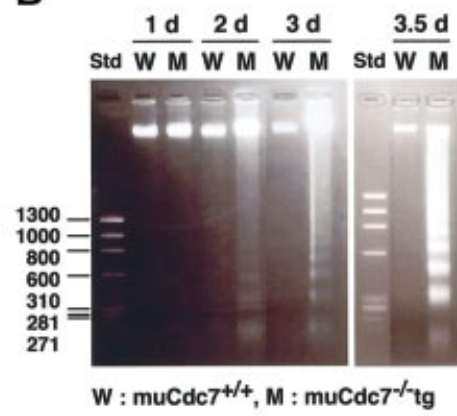

C

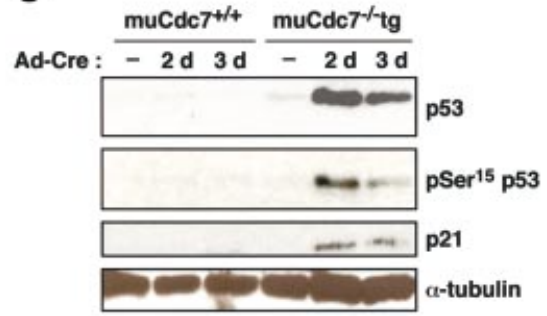

D

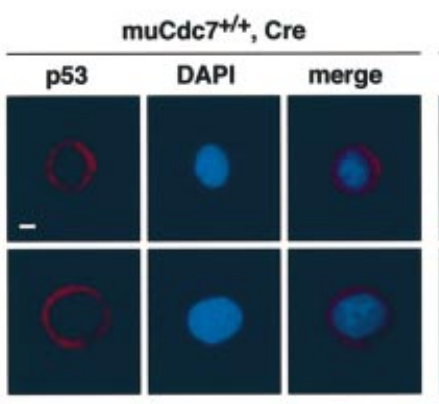

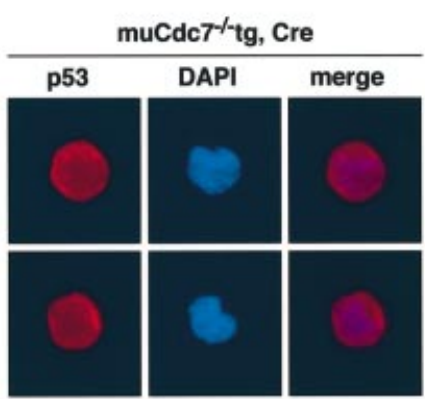

E

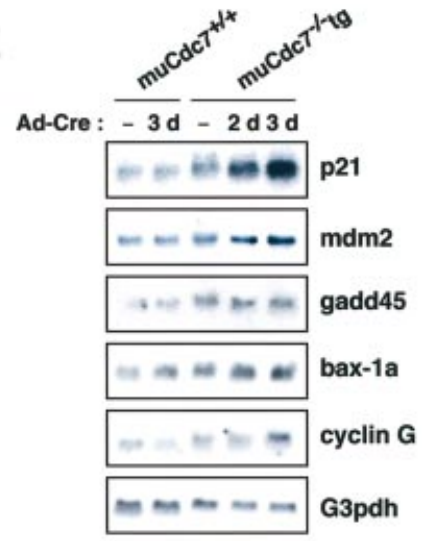

Fig. 7. Induction of cell death with concomitant activation of p53 protein in $m u C d c 7^{-/-}$ES cells. $m u C d c 7^{+/+}$and $m u C d c 7^{-/}$tg ES cells were infected with Ad-Cre at a m.o.i. of 50. (A) TUNEL assays (red) and DAPI staining (blue) of ES cells at 3.5 days after infection. Scale bar $=20 \mu \mathrm{m}$. (see Supplementary figure 1 for positive control of TUNEL assay.) (B) DNA was extracted from infected ES cells at the indicated times and was analyzed on $1.5 \%$ agarose gel. Std, DNA size marker. (C) Western blotting analysis of p53 and p21 in $m u C d c 7^{-/}$tg ES cells. Cells were harvested at the indicated times after infection and cell extracts were analyzed by immunoblotting using antibodies against p53, phosphorylated Ser ${ }^{15}$ of p53, p21 and $\alpha$-tubulin. (D) Cellular localization of p53 at 2.5 days after infection. Cells were immunostained with an antibody against p53 (red) and counterstained with DAPI (blue). Merge: merged images of p53 and DAPI staining. Scale bar $=1 \mu \mathrm{m}$. (E) Northern blot analysis of some of the p53 target genes. Fifteen micrograms of total RNA isolated from the ES cells at the indicated times after infection was run on agarose gel and blotted with the probes indicated. (See also Supplementary figure 2 for responses of the wild-type ES cells to HU and $\gamma$-ray irradiation.)

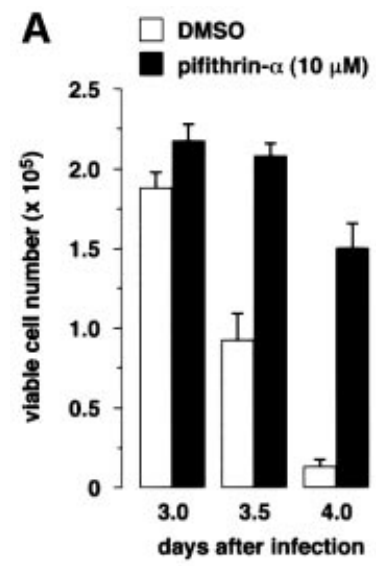

B

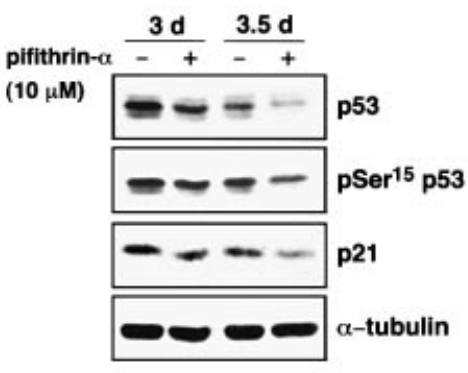

C

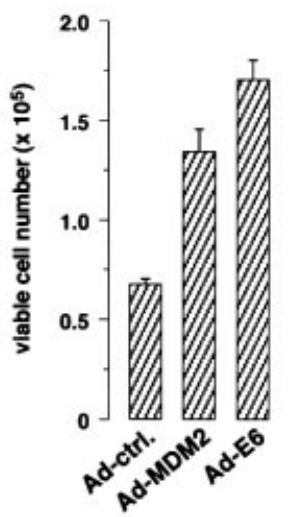

Ad-Cre infection<smiles>C1CCCCC1</smiles>

harvest,

Infection with Ad-MDM2 or Ad-E6 (or control adenovirus), plating $2 \times 10^{5}$ cells 2.5 days

count cell number

Fig. 8. p53 is required for apoptosis observed in $m u C d c 7^{-/-}$ES cells. $m u C d c 7^{+/+}$and $m u C d c 7^{-/}$tg ES cells were infected with Ad-Cre at a m.o.i. of 50. (A) Pifithrin- $\alpha(10 \mu \mathrm{M})$, a specific inhibitor of p53, or dimethylsulfoxide was (DMSO) added at day 1 after infection. Cells were collected at the indicated times after infection and the cell number was determined by Trypan Blue staining. (B) ES cells treated as in (A) were harvested at the indicated times. Cell extracts were analyzed by immunoblotting with antibodies against p53, phosphorylated Ser ${ }^{15}$ of p53, p21 and $\alpha$-tubulin. (C) $\mathrm{Mdm} 2$ or E6-expressing adenovirus was infected at day 1 after Ad-Cre infection. Cell number was determined at 3.5 days after Ad-Cre infection. In $(\mathrm{A})$ and $(\mathrm{C})$, the values are averages of three independent experiments.

Masai and Arai, 2002). In the present study, we have attempted to genetically define the roles of Cdc7 kinase in mammalian development and cell proliferation. We have done this by generating $m u C d c 7$-deficient mice as well as by exploiting a conditionally inducible gene inactivation system in ES cells. 
A
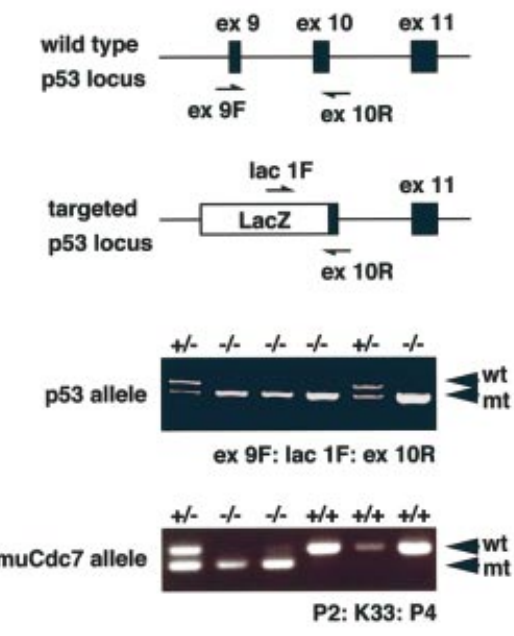

B

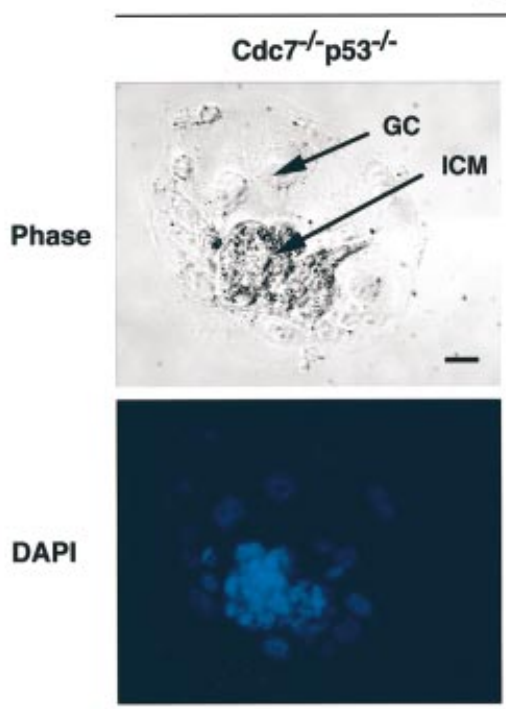

E8.5

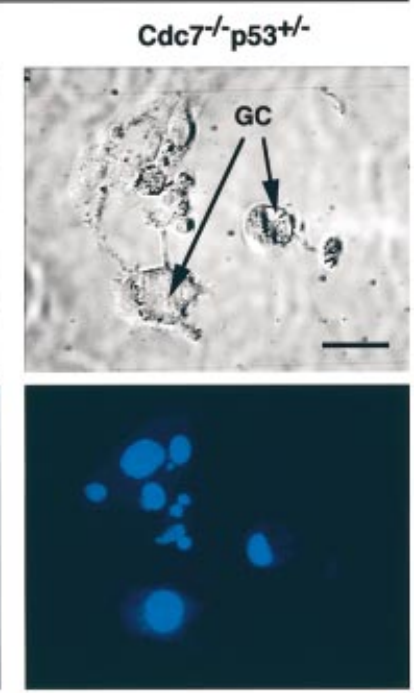

Fig. 9. Partial rescue of ICM proliferation of $m u C d c 7^{-/-}$blastocysts by $p 53$ null mutation. (A) PCR genotyping of embryos isolated from $m u C d c 7^{+/} p 53^{+/-}$intercrosses. The top illustrations show the locations of the primers (ex9F/lacIF/ex10R) used for the analysis of $p 53$ alleles (Gondo et al., 1994). Filled and open boxes indicate exons and inserted lacZ, respectively. muCdc7 allele was detected by $\mathrm{P} 2 / \mathrm{K} 33 / \mathrm{P} 4$ as in Figure $1 \mathrm{C}$. (B) Blastocysts isolated from $m u C d c 7^{+/} p 53^{+/}$intercrosses, with the genotype indicated, were cultured in vitro until E8.5. Arrows indicate ICM and GCs. Upper, phase-contrast microscopy; lower, DAPI staining. Scale bars $=50 \mu \mathrm{m}$.

Table II. Partial rescue of early embryonic lethality of $m u C d c 7$-deficient mice by $p 53$ null mutation

\begin{tabular}{|c|c|c|c|c|c|c|c|c|c|c|}
\hline \multirow{2}{*}{$\begin{array}{l}\text { Genotypes of p53 } \\
\text { Genotypes of muCdc } 7\end{array}$} & \multicolumn{3}{|c|}{ p53 $3^{+/+}$} & \multicolumn{3}{|c|}{$\mathrm{p} 53^{+/-}$} & \multicolumn{3}{|c|}{$\mathrm{p} 53^{-/-}$} & \multirow[t]{2}{*}{ Total No. } \\
\hline & $+/+$ & $+/-$ & $-1-$ & $+/+$ & $+1-$ & $-1-$ & $+/+$ & $+/-$ & $-1-$ & \\
\hline No. of E7.5 embryos & 5 & 18 & 0 & 13 & 38 & 0 & 6 & 10 & 4 & 94 \\
\hline No. of E8.5 embryos & 6 & 18 & 0 & 16 & 40 & 0 & 4 & 10 & 2 & 96 \\
\hline
\end{tabular}

\section{muCdc7 is essential for embryonic development}

We have shown that muCdc7 deficiency leads to early embryonic lethality in mice (Table I), and that $m u C d c 7$ null blastocysts cultured in vitro until E8.5 did not develop any ICM (Figure 2B). However, $m u C d c 7^{--}$GCs survived and synthesized DNA under the same conditions, and this is likely to be caused by remaining maternal stock of muCdc7 protein in undividing GCs (Figure $2 \mathrm{C}$ and D). Similarly, survival of the null embryos until E3.5 (blastocysts) may be due to the maternal muCdc7 stock. It is also possible that DNA replication of fertilized eggs may not require $\mathrm{Cdc} 7$ functions for initiation, and may be regulated by mechanisms entirely different from those of somatic cells.

\section{Strategy for generation of conditional muCdc7-deficient ES cell lines}

Since our initial attempts to generate $m u C d c 7$ knockout mice indicated that muCdc7 deficiency results in early embryonic lethality, we needed to manipulate the genome so that we can conditionally induce inactivation of the $m u C d c 7$ gene. Our strategy was to induce complete knockout of the endogenous muCdc7 in the presence of a single copy of the transgene, which encodes a $m u C d c 7$ cDNA and could support the growth of the knockout cells (Figure $3 \mathrm{~A}$ and $\mathrm{B}$ ). The transgene is flanked by the loxP sites and, therefore, can be excised. We inserted a promoterless $E G F P$ gene downstream of the transgene (outside the loxP cassette) so that it was expressed only after successful excision of the transgene and we could monitor the efficiency of excision (Figure $4 \mathrm{~A}$ and B). We used the $E F l \alpha$ promoter, which was expected to be ubiquitously active, to express the transgene, since $\mathrm{Cdc} 7$ expression is relatively constant during the cell cycle (Kim et al., 1998; Kumagai et al., 1999). The complete loss of the endogenous $m u C d c 7$ alleles could be efficiently achieved by screening for the survivors in the presence of higher concentration of G418. When this was conducted on the heterozygous $m u C d c 7^{+/} \mathrm{ES}$ cells in the absence of a transgene, very few survivors were obtained and they did not have expected chromosome structures at the $m u C d c 7$ locus (data not shown). In contrast, in the presence of the transgene, the cell lines with complete disruption of both alleles were readily obtained (Figure 3D), and these mutant cell lines were indistinguishable from the wildtype cells in terms of growth properties (data not shown). This indicates that constitutive expression of the 532 amino acid form of muCdc7 can fully support normal growth of ES cells.

Upon infection of these cell lines with adenoviruses encoding the Cre recombinase, EGFP expression was induced within 1 day and almost 100\% of the cell 
population was positive for EGFP (Figure 4A and B), indicating that excision of the transgene took place efficiently. We obtained 11 independent clones expressing a transgene and in all cases the transgene was efficiently excised by Cre recombinase, indicating that the method could generally work in generating mutant ES cells, in which essential genes are conditionally inactivated.

\section{Loss of muCdc7 leads to S-phase arrest, induction of recombinational repair and the $G_{2} / M$ checkpoint}

The mutant ES cells rapidly ceased the increase in cell numbers and DNA synthesis following inactivation of muCdc7 (Figure 5A-C). Unexpectedly, analysis of DNA content revealed S-phase arrest of Cdc7-depleted ES cells (Figure 5D), rather than $G_{1} / S$ arrest with DNA content of unreplicated cells, which is observed in yeasts under the equivalent condition. In budding yeast, replication forks derived from early firing origins can complete the replication of the entire chromosomes in the absence of firing of late origins. In ES cells, in contrast, the loss of firing from late origins causes rather immediate cessation of DNA synthesis and results in suspended $\mathrm{S}$ phase, indicating that the chromosomal DNA replication cannot be completed in the absence of continuous firing of origins. This difference may be due to much larger sizes of the mammalian chromosomes, the replication of which would require firing of thousands of origins under normal growing conditions. The replication forks from the early firing origins would continue to travel along the chromosome, but would be likely to encounter obstacles along the way, which would halt their progression or disintegrate the replicative complexes at the forks. Alternatively, collision of ongoing replication forks with unfired prereplicative complex may arrest the forks in ES cells. It is also possible that mammalian $\mathrm{Cdc} 7$ may target molecules essential for DNA chain elongation.

Whatever the case, the arrested replication forks generate checkpoint signals so that the cell cycle progression is temporally suspended and the forks are rescued (Hartwell and Weinert, 1989; Elledge, 1996; Chan et al., 2000). We have shown that this is indeed the case in $m u C d c 7^{-1-}$ ES cells by showing induction of phosphorylation of $\mathrm{Cdc} 2$ on tyrosine 15 and the absence of histone H3 phosphorylation, as well as formation of nuclear Rad51 foci (Figure 6).

\section{p53-dependent cell death induced by replication fork block in ES cells}

We have shown that inactivation of muCdc7 in ES cells eventually induces cell death, and that it depends on the p53 function. Extension of the lifespan of $m u C d c 7^{-/}$ embryos by $p 53^{--}$mutation also suggests the occurrence of p53-dependent cell death in early embryogenesis upon loss of muCdc7.

The wild-type ES cells undergo rapid cell death upon treatment with HU as well, with concomitant induction of nuclear Rad51 foci and p53 protein (Figure 6A; Supplementary figure 2 available at The EMBO Journal Online). Thus, ES cells appear to be particularly sensitive to S-phase arrest. Transcription of $p 21, m d m 2$ and cyclin $G$ target genes of p53, is induced in ES cells after inactivation of muCdc7 or treatment with HU (Figure 7E;
Supplementary figure 2). This is in contrast to differentiated mammalian cells, in which p53 protein is stabilized but target genes are generally not induced in response to replication block (Gottifredi et al., 2001). We consider the following possibilities to explain this difference. (i) A unique signal transduction pathway is induced by replication fork block in undifferentiated ES cells, which generates transcriptionally active p53, whereas, in differentiated cells, p53 protein, although stabilized, is somehow rendered inactive after S-phase arrest. (ii) The number of arrested replication forks is larger in undifferentiated ES cells, resulting in a higher level of checkpoint signals and hyperactivation of p53. In fact, the numbers of Rad51 foci of ES cells arrested in S phase by inactivation of muCdc7 as well as by HU are larger than that of $\gamma$-rayirradiated ES cells (Figure 6A), in which cells are arrested at $\mathrm{G}_{2} / \mathrm{M}$ phase without significant cell death (see Supplementary figure 2). (iii) It could simply be due to the level of endogenous p53, which, in an unperturbed state, is higher in undifferentiated ES cells than in differentiated cells. Whatever the mechanism, the tendency of ES cells to undergo apoptosis in response to replication fork block would facilitate the maintenance of high genomic integrity as a population, and this characteristic would be highly desirable for those cells with tautipotency.

In summary, our results demonstrate the essential roles of Cdc7 kinase in DNA synthesis and cell proliferation of mammalian cells, and that the absence of $\mathrm{Cdc} 7$ kinase leads to S-phase arrest, which generates DNA structure checkpoint signals resulting in recombinational repair and eventual p53-dependent cell death.

\section{Materials and methods}

\section{Cells}

The parental ES cell line used in this study was CCE 28. ES cells were maintained on a layer of mitomycin C-treated feeder cells in Dulbecco's modified Eagle's medium, supplemented with $20 \%$ fetal bovine serum, $2 \mathrm{mM}$ L-glutamine, $0.1 \mathrm{mM}$ non-essential amino acids and $0.1 \mathrm{mM}$ $\beta$-mercaptoethanol in the presence of $10^{3} \mathrm{U} / \mathrm{ml}$ murine leukemia inhibitory factor (LIF).

\section{Generation of muCdc7 knockout mice}

The targeting vector plasmid, in which the $4.3 \mathrm{~kb}$ DNA fragment containing exons 3 and 4 (encoding essential kinase domains I and II) of $m u C d c 7$ was replaced with a $1.1 \mathrm{~kb}$ pMC1-neomycin resistance cassette $\left(n e o^{\mathrm{r}}\right)$, was linearized and electroporated into CCE 28 ES cells. Transformants were selected by resistance to $\mathrm{G} 418$ at $250 \mu \mathrm{g} / \mathrm{ml}$ for the presence of the $n e o^{r}$ genes, and by resistance to ganciclovir at $5 \mu \mathrm{M}$ for the absence of the $t k$ gene.

\section{Construction of a flox transgene vector}

The flox transgene plasmid containing a hEF1 $\alpha$ promoter-driven wildtype $m u C d c 7$ cDNA flanked by the loxP sites (Figure 3B) was constructed as follows. First, pEF1 $\alpha$-loxP-p(A)-loxP-EGFP was constructed by inserting the EGFP coding region at the $S w a \mathrm{I}$ site of $\mathrm{pEF} 1 \alpha-\operatorname{lox} P-\mathrm{p}(\mathrm{A})-$ lox $P$, in which the original chicken $\beta$-actin gene (CAG) promoter of pCAG-loxP-p(A)-loxP was replaced with hEF1 $\alpha$ promoter (kindly provided by Dr Sumio Sugano). The muCdc7-PGKpuro ${ }^{\mathrm{r}}$ cassette, constructed by inserting a $m u C d c 7$ cDNA fragment into the pPGKPuro-p(A) plasmid, was cloned at the NotI site present between the two loxP sites, resulting in the flox transgene vector $\mathrm{pEF} 1 \alpha-$ lox $P$-muCdc7PGKpuro ${ }^{\mathrm{r}}$-loxP-EGFP. 


\section{Generation of muCdc7-/- ES cells carrying a muCdc7 transgene}

The flox muCdc7 transgene $\mathrm{pEF} 1 \alpha$-loxP-muCdc7-PGKpuro ${ }^{\mathrm{r}}$-loxP-EGFP was introduced into one of the $\mathrm{muCdc7^{+/ }}$ ES clones by electroporation, and transfected cells were cultured in the presence of $0.6 \mu \mathrm{g} / \mathrm{ml}$ puromycin for 8 days. Southern blotting and RT-PCR were conducted to identify four puromycin-resistant clones ( $\mathrm{muCdc} 7^{+/}$tg ES clones), which carried a single copy of the transgene on a chromosome and transcribed the transgene-derived mRNA. The primer set, 'rt-EFs' and 'tMCas', amplified a $370 \mathrm{bp}$ fragment from the mRNA product of the transgene. We then generated $m u C d c 7^{-/} \operatorname{tg}$ ES clones by culturing one of the $\mathrm{muCdc} 7^{+/} \mathrm{tg}$ ES clones in the presence of an increased concentration of $\mathrm{G} 418(3 \mathrm{mg} / \mathrm{ml})$.

\section{Infection of ES cells with adenoviruses}

AxCANCre (Ad-Cre; Kanegae et al., 1995) was amplified on 293 cells and purified by two rounds of $\mathrm{CsCl}$ density centrifugation. Ad-Mdm2, Ad-E6 and Ad-ctrl were gifts from Cyrus Vaziri (Nghiem et al., 2001). Added to ES cells, resuspended in a small volume of ES medium, were recombinant adenoviruses at a m.o.i. of 50 (Ad-Cre) or a m.o.i. of 200 (Ad-ctrl, Ad-Mdm2 and Ad-E6). After incubation for $1 \mathrm{~h}$, cells were diluted with fresh ES medium containing murine LIF $\left(10^{4} \mathrm{U} / \mathrm{ml}\right)$ and plated in 6-well gelatinized plates. The cultures were maintained with daily change of the media.

\section{Supplementary data}

Supplementary data for this paper are available at The EMBO Journal Online.

\section{Acknowledgements}

We thank Cyrus Vaziri for generous gifts of recombinant adenoviruses. We also thank Miho Nagoya for assistance in experiments with mice, and Naofumi Takemoto for critical reading of manuscript. We thank the members of the Katsuki laboratory and our laboratory for help and helpful discussion.

\section{References}

Aladjem,M.I., Spike,B.T., Rodewald,L.W., Hope,T.J., Klemm,M., Jaenisch,R. and Wahl.G.M. (1998) ES cells do not activate p53dependent stress responses and undergo p53-independent apoptosis in response to DNA damage. Curr. Biol., 8, 145-155.

Aparicio,O.M., Weinstein,D.M. and Bell,S.P. (1997) Components and dynamics of DNA replication complexes in $S$. cerevisiae: redistribution of MCM proteins and Cdc45p during S phase. Cell, 91, 59-69.

Baldin,V., Lukas,J., Marcote,M.J., Pagano,M. and Draetta,G. (1993) Cyclin D1 is a nuclear protein required for cell cycle progression in $\mathrm{G}_{1}$. Genes Dev., 7, 812-821.

Banin,S. et al. (1998) Enhanced phosphorylation of p53 by ATM in response to DNA damage. Science, 281, 1674-1677.

Bousset,K. and Diffley,J.F. (1998) The Cdc7 protein kinase is required for origin firing during S phase. Genes Dev., 12, 480-490.

Bradbury,E.M. (1992) Reversible histone modifications and the chromosome cell cycle. BioEssays, 14, 9-16.

Brown,G.W. and Kelly,T.J. (1998) Purification of Hsk1, a minichromosome maintenance protein kinase from fission yeast. J. Biol. Chem., 273, 22083-22090.

Buck,V., White,A. and Rosamond,J. (1991) CDC7 protein kinase activity is required for mitosis and meiosis in Saccharomyces cerevisiae. Mol. Gen. Genet., 227, 452-457.

Canman,C.E., $\quad$ Lim,D.S., $\quad$ Cimprich,K.A., $\quad$ Taya,Y., Tamai,K., Sakaguchi,K., Appella,E., Kastan,M.B. and Siliciano,J.D. (1998) Activation of ATM kinase by ionizing radiation and phosphorylation of p53. Science, 281, 1677-1679.

Carr,A.M. (1996) Checkpoints take the next step. Science, 271, 314-315.

Chan,T.A., Hwang,P.M., Hermeking,H., Kinzler,K.W. and Vogelstein,B. (2000) Cooperative effects of genes controlling the $\mathrm{G}_{2} / \mathrm{M}$ checkpoint. Genes Dev., 14, 1584-1588.

Chapman,J.W. and Johnston,L.H. (1989) The yeast gene, DBF4, essential for entry into $\mathrm{S}$ phase is cell cycle regulated. Exp. Cell Res., 180, 419-428.

Chong,J.P., Thommes,P. and Blow,J.J. (1996) The role of MCM/P1 proteins in the licensing of DNA replication. Trends Biochem. Sci., 21, 102-106.

Donaldson,A.D., Fangman,W.L. and Brewer,B.J. (1998) Cdc7 is required throughout the yeast $S$ phase to activate replication origins. Genes Dev., 12, 491-501.

Dutta,A. and Bell,S.P. (1997) Initiation of DNA replication in eukaryotic cells. Annu. Rev. Cell Dev. Biol., 13, 293-332.

Elledge,S.J. (1996) Cell cycle checkpoints: preventing an identity crisis. Science, 274, 1664-1672.

Furnari,B., Rhind,N. and Russell,P. (1997) Cdc25 mitotic inducer targeted by chk1 DNA damage checkpoint kinase. Science, 277, 1495-1497.

Gondo,Y., Nakamura,K., Nakao,K., Sasaoka,T., Ito,K., Kimura,M. and Katsuki,M. (1994) Gene replacement of the p53 gene with the lacZ gene in mouse embryonic stem cells and mice by using two steps of homologous recombination. Biochem. Biophys. Res. Commun., 202, 830-837.

Gottifredi,V., Shieh,S.Y., Taya,Y. and Prives,C. (2001) p53 accumulates but is functionally impaired when DNA synthesis is blocked. Proc. Natl Acad. Sci. USA, 98, 1036-1041.

Haaf,T., Golub,E.I., Reddy,G., Radding,C.M. and Ward,D.C. (1995) Nuclear foci of mammalian Rad51 recombination protein in somatic cells after DNA damage and its localization in synaptonemal complexes. Proc. Natl Acad. Sci. USA, 92, 2298-2302.

Hansen,R. and Oren,M. (1997) p53: from inductive signal to cellular effect. Curr. Opin. Genet. Dev., 7, 46-51.

Hartwell,L.H. (1971) Genetic control of the cell cycle in yeast II. Genes controlling DNA replication and its initiation. J. Mol. Biol., 59, 183-194.

Hartwell,L.H. and Weinert,T.A. (1989) Checkpoints: controls that ensure the order of cell cycle events. Science, 246, 629-634.

Haupt,Y., Maya,R., Kazaz,A. and Oren,M. (1997) Mdm2 promotes the rapid degradation of p53. Nature, 387, 296-299.

Hollingsworth,J.R.E. and Sclafani,R. (1990) DNA metabolism gene CDC7 from yeast encodes a serine/threonine protein kinase. Proc. Natl Acad. Sci. USA, 87, 6272-6276.

Ishimi,Y. (1997) A DNA helicase activity is associated with an MCM4, -6, and -7 protein complex. J. Biol. Chem., 272, 24508-24513.

Jackson,A.L., Pahl,P.M.B., Harrison,K., Rosamond,J. and Sclafani,R.A. (1993) Cell cycle regulation of the yeast Cdc7 protein kinase by association with the Dbf4 protein. Mol. Cell. Biol., 13, 2899-2908.

Jares,P. and Blow,J.J. (2000) Xenopus Cdc7 function is dependent on licensing but not on XORC, XCdc6, or CDK activity and is required for XCdc45 loading. Genes Dev., 14, 1528-1540.

Jiang,W. and Hunter,T. (1997) Identification and characterization of a human protein kinase related to budding yeast Cdc7p. Proc. Natl Acad. Sci. USA, 94, 14320-14325.

Jiang,W., McDonald,D., Hope,T.J. and Hunter,T. (1999) Mammalian Cdc7-Dbf4 protein kinase complex is essential for initiation of DNA replication. EMBO J., 18, 5703-5713.

Johnston,L.H., Masai,H. and Sugino,A. (1999) First the CDKs, now the DDKs. Trends Cell Biol., 9, 249-252.

Kanegae,Y., Lee,G., Sato,Y., Tanaka,M., Nakai,M., Sakaki,T., Sugano,S. and Saito,I. (1995) Efficient gene activation in mammalian cells by using recombinant adenovirus expressing sitespecific Cre recombinase. Nucleic Acids Res., 23, 3816-3821.

Kearsey,S.E., Labib,K. and Maiorano,D. (1996) Cell cycle control of eukaryotic DNA replication. Curr. Opin. Genet. Dev., 6, 208-214.

Kim,J.M., Sato,N., Yamada,M., Arai,K. and Masai,H. (1998) Growth regulation of the expression of mouse cDNA and gene encoding a serine/threonine kinase related to Saccharomyces cerevisiae CDC7 essential for $\mathrm{G}_{1} / \mathrm{S}$ transition. J. Biol. Chem., 273, 23248-23257.

Komarov,P.G., Komarova,E., Kondratov,R.V., Christov-Tselkov,K., Coon,J.S., Chernov,M.V. and Gudkov,A.V. (1999) A chemical inhibitor of p53 that protects mice from the side effects of cancer therapy. Science, 285, 1733-1737.

Kubbutat,M.H., Jones,S.N. and Vousden,K.H. (1997) Regulation of p53 stability by Mdm2. Nature, 387, 299-303.

Kumagai,H., Sato,N., Yamada,M., Mahony,D., Seghezzi,W., Lees,E., Arai,K. and Masai,H. (1999) A novel growth- and cell cycle-regulated protein, ASK, activates human Cdc7-related kinase and is essential for $\mathrm{G}_{1} / \mathrm{S}$ transition in mammalian cells. Mol. Cell. Biol., 19, 5083-5095.

Labib,K. and Diffley,J.F. (2001) Is the MCM2-7 complex the eukaryotic DNA replication fork helicase? Curr. Opin. Genet. Dev., 11, 64-70. 
Lei,M. and Tye,B.K. (2001) Initiating DNA synthesis: from recruiting to activating the MCM complex. J. Cell Sci., 114, 1447-1454.

Lei,M., Kawasaki,Y., Young,M.R., Kihara,M., Sugino,A. and Tye,B.K. (1997) $\mathrm{Mcm} 2$ is a target of regulation by Cdc7-Dbf4 during the initiation of DNA synthesis. Genes Dev., 11, 3365-3374.

Levine,A.J. (1997) p53, the cellular gatekeeper for growth and division. Cell, 88, 323-331.

Lutzker,S.G. and Levine,A.J. (1996) A functionally inactive p53 protein in teratocarcinoma cells is activated by either DNA damage or cellular differentiation. Nature Med., 2, 804-810.

Masai,H. and Arai,K. (2002) Cdc7 kinase complex: a key regulator in the initiation of DNA replication. J. Cell Physiol., 190, 287-296.

Masai,H., Miyake,T. and Arai,K. (1995) $h s k 1^{+}$, a Schizosaccharomyces pombe gene related to Saccharomyces cerevisiae $C D C 7$, is required for chromosomal replication. EMBO J., 14, 3094-3104.

Mortensen,R.M., Conner,D.A., Chao,S., Geisterfer-Lowrance,A.A. and Seidman,J.G. (1992) Production of homozygous mutant ES cells with a single targeting construct. Mol. Cell. Biol., 12, 2391-2395.

Nghiem,P., Park,P.K., Kim,Y.S., Vaziri,C. and Schreiber,S.L. (2001) ATR inhibition selectively sensitizes $\mathrm{G}_{1}$ checkpoint-deficient cells to lethal premature chromatin condensation. Proc. Natl Acad. Sci. USA, 98, 9092-9097.

Ohtsubo,M., Theodoras,A.M., Schumacher,J., Roberts,J.M. and Pagano,M. (1995) Human cyclin E, a nuclear protein essential for the $\mathrm{G}_{1}$-to-S phase transition. Mol. Cell. Biol., 15, 2612-2624.

Roberts,B.T., Ying,C.Y., Gautier,J. and Maller,J.L. (1999) DNA replication in vertebrates requires a homolog of the $\mathrm{Cdc} 7$ protein kinase. Proc. Natl Acad. Sci. USA, 96, 2800-2804.

Rugh,R. (1990) Normal development of the mouse. The Mouse. Oxford University Press, London, UK, pp. 44-101.

Sabapathy,K., Klemm,M., Jaenisch,R. and Wagner,E.F. (1997) Regulation of ES cell differentiation by functional and conformational modulation of p53. EMBO J., 16, 6217-6229.

Sanchez,Y., Wong,C., Thoma,R.S., Richman,R., Wu,Z., Piwnica-Worms,H. and Elledge,S.J. (1997) Conservation of the Chk1 checkpoint pathway in mammals: linkage of DNA damage to Cdk regulation through Cdc25. Science, 277, 1497-1501.

Sato,N., Arai,K. and Masai,H. (1997) Human and Xenopus cDNAs encoding budding yeast Cdc7-related kinases: in vitro phosphorylation of MCM subunits by a putative human homologue of Cdc7. EMBO J., 16, 4340-4351.

Savatier,P., Huang,S., Szekely,L., Wiman,K.G. and Samarut,J. (1994) Contrasting patterns of retinoblastoma protein expression in mouse embryonic stem cells and embryonic fibroblasts. Oncogene, 9, 809-818.

Sclafani,R.A. (2000) Cdc7p-Dbf4p becomes famous in the cell cycle. J. Cell Sci., 113, 2111-2117.

Sclafani,R.A. and Jackson,A.L. (1994) Cdc7 protein kinase for DNA metabolism comes of age. Mol. Microbiol., 11, 805-810.

Sherr,C.J. (1993) Mammalian $\mathrm{G}_{1}$ cyclins. Cell, 73, 1059-1065.

Sherr,C.J. (1994) $\mathrm{G}_{1}$ phase progression: cycling on cue. Cell, 79, 551-555.

Shieh,S.Y., Ahn,J., Tamai,K., Taya,Y. and Prives,C. (2000) The human homologs of checkpoint kinases Chk1 and Cds1(Chk2) phosphorylate p53 at multiple DNA damage-inducible sites. Genes Dev., 14, $1439-1447$.

Stillman,B. (1996) Cell cycle control of DNA replication. Science, 274, 1659-1664.

Takeda,T., Ogino,K., Matsui,E., Cho,M.K., Kumagai,H., Miyake,T., Arai,K. and Masai,H. (1999) A fission yeast gene, $\operatorname{him} 1^{+} / d f p 1^{+}$, encoding a regulatory subunit for Hsk1 kinase, plays essential roles in S-phase initiation as well as in S-phase checkpoint control and recovery from DNA damage. Mol. Cell. Biol., 19, 5535-5547.

Thompson,D.A., Belinsky,G., Chang,T.H., Jones,D.L., Schlegel,R. and Munger,K. (1997) The human papillomavirus-16 E6 oncoprotein decreases the vigilance of mitotic checkpoints. Oncogene, 15, 3025-3035.

Tibbetts,R.S., Brumbaugh,K.M., Williams,J.M., Sarkaria,J.N., Cliby, W.A., Shieh,S.Y., Taya,Y., Prives,C. and Abraham,R.T. (1999) A role for ATR in the DNA damage-induced phosphorylation of p53. Genes Dev., 13, 152-157.

Walter,J.C. (2000) Evidence for sequential action of cdc7 and cdk2 protein kinases during initiation of DNA replication in Xenopus egg extracts. J. Biol. Chem., 275, 39773-39778.

Weinreich,M. and Stillman,B. (1999) Cdc7p-Dbf4p kinase binds to chromatin during S phase and is regulated by both the APC and the RAD53 checkpoint pathway. EMBO J., 18, 5334-5346.
Zou,L. and Stillman,B. (2000) Assembly of a complex containing Cdc45p, replication protein $A$, and $\mathrm{Mcm} 2 \mathrm{p}$ at replication origins controlled by S-phase cyclin-dependent kinases and Cdc7p-Dbf4p kinase. Mol. Cell. Biol., 20, 3086-3096.

Received August 30, 2001; revised February 18, 2002; accepted March 15, 2002 